\title{
Parakkisosialismia pohtiessa
}

\author{
Ville Ropponen: Suuren idän essee. Savukei- \\ das, 2017. 240 s. ISBN: 978-952-26-8197-3.
}

\section{Ville Ropponen ja Ville-Juhani Sutinen: Luiden tie. Gulagin jäljillä, Like, 2019. 399 s. ISBN: 978-952-01-1842-6.}

Miten kirjoittaa valtiosta, joka oman ilmoituksensa mukaan edusti maailmanhistorian siihen asti ylintä ja jopa tieteellisesti edistyneintä tasoa, mutta joka oli nimeään myöten väärennös? Toimittaja ja matkakirjailija Ville Ropponen hakee ratkaisua kahdesta suunnasta: ensin hän lähestyy Neuvostoliittoa kokeellisen, sitten konventionaalisen tekstin avulla.

Kokeellinen tai ainakin temppuileva teksti on nimeltään Suuren idän essee. Lajityypiltään kirja on siis essee - takakannen kielellisesti kammottavan maininnan mukaan "nonfiktioteos" - ja esseen luonnetta tekijä pariin otteeseen eritteleekin. Essee edellyttää "erilaisia tyylejä, vaihtelevaa, törmäilevää diskurssia ja rekisterinrikkojia", hän linjaa. Niinpä opimme Ropposen lapsuudesta ja nuoruudesta, matkoista ja mietteistä, lukemisista ja lopulta ties mistä.

Selväksi tulee, että alun toistasataa vuotta sitten Venäjällä lanseerattu yhteiskuntakokeilu oli perin juurin kelvoton. Neuvostoliitto oli "kuvitelmaa, houretta alusta loppuun", Ropponen huudahtaa. Sosialistisena esiintynyt järjestelmä ei edes ollut sosialistinen; Neuvostoliitossa oli saman verran "sosialismin aatetta" kuin inkvisitiossa kristinuskon sanomaa rakkaudesta. Ropposen tutkimuksellinen auktoriteetti vaikuttaisi olevan historioitsija Osmo Jussila, joka toistuvasti muistutti bolsevikkien valtiollisen luomuksen epämääräisyydestä. Sosialististen Neuvostotasavaltojen Liittoa ei "koskaan ollut olemassakaan: se ei ollut sosialistinen, ei neuvostovalta, ei tasavaltainen eikä valtioiden liitto", Jussila järkeili Neuvostoliiton jo luhistuttua (Historiallinen Aikakauskirja 1/1994). Ropposen muotoilemalla kritiikillä on kuitenkin vielä pidempi - ja maineikas - historia vasemmistolaisessa viitekehyksessä. Leninin ja Trotskin tapaisten bolševikkien sanottiin välittömästi, itse asiassa jo ennen loppuvuoden 1917 vallankaappausta, väärentäneen sosialismin ja ylipäänsä marksismin idean.

Kun kerran sosialismia ei sinänsä sovi syyttää, mikä sitten selittäisi maamme itärajan taakse kohonneen hirmuvallan? Nyt on puhuttava nimenomaan hirmuvallasta, sillä Ropposen mukaan edes Dostojevskin mielikuvitus ei olisi riittänyt käsittämään Stalinin kauden pakkotyöverkoston mittasuhteita. "Siellä tappotyö, huudot, klimppisoppa ja hakkaaminen olivat satojen tuhansien ihmisten arkipäivää”, tekijä selostaa käyntiään Karagandassa, nykyisen Kazakstanin alueella.

Syyllistä on haettava Venäjän omasta historiasta. Ensiksi Ropponen mainitsee Hannah Arendtia lainaten "panslavismin", sitten Nikolai Berdjajeviin vedoten "venäläisen kulttuurin syvävirtaukset". Tätä kautta siis selittyisi bolševismin kiivas olemus valtaisine ruumiskasoineen. Matkailevan esseistin sopiikin luottaa Berdjajevin filosofiseen esseistiikkaan, ovathan niin tehneet myös monet tutkijat. Ortodoksisen Venäjän "syväjuonteisiin" nojaaminen on silti uskonvarainen valinta. Berdjajevin viihdyttävän tuotannon empiirisestä ohuudesta on hiljattain kirjoittanut Ana Siljak (The Journal of Modern History 4/2016), jonka analyysin jäljiltä "venäläinen messianismi" paljastuu suurin piirtein samanveroiseksi fiktioksi kuin Neuvostoliiton tieteellisesti todisteltu edistyksellisyys.

Kaikkiruokaisena proosana Suuren idän essee sisältää provosoivia sivupolkuja muun muassa Aleksandr Solženitsynin ajatteluun ("uusslavofilil" Ropposen mukaan), Olavi Paavolaisen 1930-luvun Neuvostoliiton-kiertueeseen (nielaisi neuvostopropagandan "lähes karvoineen") ja Katja Ketun Kätilö-romaaniin (Venäjää herjaava "kummitustarina"). Kokoavaa teesiä ei löydy eikä täydykään löytyä: "houreinen" Neuvostoliitto oikeuttaa mitä moninaisimmat mielijohteet.

Ville Ropposen konventionaalinen kirja on syntynyt yhteistyössä toisen esseistin, VilleJuhani Sutisen kanssa. Luiden tiessä Villet vievät lukijaa gulagin eli Neuvostoliiton pakkotyöleirien jäänteille, ja sen he tekevät niin vähäeleisesti, että satunnainen maininta "vanhaan kunnon tyyliin" toteutetuista teloituksista pomppaa tarpeettomasti silmään. Ohikiitävä viittaus tuon valtion valesosialismiin ei sitä vastoin yllätä: 
Neuvostoliitossa "ei ollut sosialismia eikä neuvostojen valtaa, kuten historioitsija Osmo Jussila on todennut".

Ropponen ja Sutinen kartoittavat neuvostoleirejä laajalla säteellä Vienanmereltä Kolymaan, Karagandasta Vorkutaan. Kuvitus on paitsi runsasta myös laadukasta, vain matkamiesten kiertueita havainnollistava kartta puuttuu. Alan keskeinen kirjallisuus on luettu ja nivelletty historiajaksoihin, joissa huomioidaan keisarillisen Venäjän pakkotyöjärjestelmä ilman että se samastettaisiin vuoden 1917 jälkeisiin leireihin. Kirjalistasta uupuu ainoastaan yksi perusteos, puolalaisen Tomasz Kiznyn monumentaalinen matka- ja kuvakirja Gulag, joka ilmestyi 2000-luvun alussa lukuisina laitoksina.

Kiznyn jäljissä kulkevilla suomalaisilla on ajan tuomaa lisäperspektiiviä pohdintoihinsa. Valtioterrorin perinnöstä puhutaan suorastaan oppinein sanankääntein, ja paikallisten kanssa käydyt keskustelut ovat nekin erinomaisen valaisevia. Matkaajamme mielivät myös muistuttaa siitä oleellisesta seikasta, että gulag ei ole nykyVenäjällä mikään tabu, toisin kuin ajoittaisten hälyotsikoiden perusteella voisi ajatella. "Sorron tarinaa kertovat yksityiset ihmiset, kansalaisjärjestöt ja ortodoksikirkko", Ropponen ja Sutinen lausahtavat. "Joskus ne saavat siihen tukea, joskus niitä häiritään."

Tuoreemman leirikirjallisuuden ohella kaksikko lainaa toistuvasti Vankileirien saaristoa (Arhipelag GULAG, suom. ilm. 1974-1978), Solženitsynin pääosin 1960-luvulla laatimaa teossarjaa. Ehkä juuri sen eepoksen vaikutuksen alla he tekevät hillittyjä vertailuja natsileireihin, vertailuja, jotka takavuosina koettiin joissakin piireissä sopimattomiksi. Tässä yhteydessä täytyykin mainita Sutisen ja Silja Pitkäsen mainio matkakirja Kolmannen valtakunnan keskitysleirit (2014). "Näillä kahdella järjestelmällä oli kuitenkin ratkaisevia eroja, eikä niitä voi suoraan rinnastaa", Ropponen ja Sutinen tarkentavat.

Neuvostoleirit Solženitsyn toi tunnetulla tavalla julkisuuteen esikoisteoksellaan Ivan Denisovitšin päivä (Odin den Ivana Denisovitša, 1962). Kahden Villen kirjassa tuo kohukertomus esitellään hivenen harhauttavasti. Toisin kuin tekijät väittävät, Solženitsyn ei joutunut sensorin käskystä muokkaamaan lopetusta "myönteisempään" suuntaan. Yhtä omituinen on näkemys, jonka mukaan nimihenkilön "henkinen rakenne" murtuisi kertomuksen edetessä. Tutkimuksellinen konsensus (ja tekijän intentio) todistaa päinvastaista: Ivan Denisovitšin talonpoikainen neuvokkuus ei murene edes työleirin kurimuksessa.

Tuollainen kritiikki ei tietenkään vähennä Luiden tien arvoa kiehtovana matkakirjana ja neuvostoterrorin pätevänä kronikkana. Kun samalta firmalta on jo aiemmin ilmestynyt KlasGöran Karlssonin Vaino ja vaikeneminen (Terror och tystnad, 2010) sekä Stephen F. Cohenin Gulagista selvinneet (The Victims Return, 2013), Liken voidaan todeta ponnahtaneen leirikirjallisuuden johtavaksi kustantajaksi tässä maassa. Mutta missä viipyy kattava tutkimus tai tietokirja gulagin tuhansista suomalaisista vangeista? Heidän kohtaloihinsa Ropponen ja Sutinen kevyesti viittailevat. Vaikka Venäjän kaikkiin arkistoihin ei vieläkään olisi pääsyä, materiaalia luulisi kyllä karttuneen tuhtiin, kansallisesti mitä tärkeimpään kirjaan, joka kattaisi suurimman osan reaalisosialistisen naapurimme historiasta.

Erkki Vettenniemi

\section{Suuret ajat vaativat suuria oppaita}

\section{Rob Sears: Vladimir Putin - Menestyvän johtajan opetukset. Maailman mahtavimman miehen vinkit oman elämän valtiuteen. Helsin- ki: Aula \& Co, 2018. Suom. Anna Tuomikoski. 156 s. ISBN 978-952-7269-40-4.}

Elämäntaito-oppaat, eli "self-help" (tai "selfimprovement") -kirjallisuus, ovat melko vähän tutkittu ja ehkä myös hieman ylenkatsottu tietokirjallisuuden alalaji. Kyseessä on myös hyvin amerikkalaiseksi koettu genre. Pienen ihmisen pyrkimys onneen ja stressittömään elämään myönteisen ajattelun ja miksei ulkoisen menestyksenkin kautta kiteyttää toki jotain olennaista "amerikkalaisesta unelmasta". Yksi kaikkien aikojen kuuluisimmista oppaista on köyhästä farmarin pojasta uraauurtavaksi motivaatiokouluttajaksi nousseen Dale Carnegien teos Miten saan ystäviä, menestystä ja vaikutusvaltaa (How to Win Friends and Influence People, 1936, 